\title{
NITROGEN DIOXIDE DISTRIBUTION AND THE BACTERIAL LOAD IN AIR AROUND A COMPOSTING FACILITY
}

\section{Distribuição de Dióxido de Nitrogênio e da carga bacteriana no ar nas imediações de uma fábrica de adubo}

Ukpebor J. E. ${ }^{1}$

Ukpebor, E. E. ${ }^{2}$

Ekhaise, F. O. ${ }^{2}$

\begin{abstract}
The composting facility at Eruemu has been appraised with particular reference to its impact on the Nitrogen dioxide and microbial load in air within and around the facility. Previous assessment of the ambient air within this facility indicated that its operation could be a potential significant source of $\mathrm{NH}_{3}$ and $\mathrm{H}_{2} \mathrm{~S}$ in the environment. In this study, nitrogen dioxide monitoring was done every forthnight using Palmes diffusion tubes. For the microbial assessment, air sampling was carried out using the filtration method described by Albrecht. The total heterotrophic bacterial population ranged from $1 \mathrm{cfu} / \mathrm{ml}$ to $67 \mathrm{cfu} / \mathrm{ml}$, with the higher bacterial count recorded for site B. No pathogenic bacterial isolates were detected in the air samples collected from the different monitoring sites. Low levels of the acidic gas $\mathrm{NO}_{2}$ was obtained at all the monitoring sites. Significant spatial variation ( $\mathrm{p}<0.05$ at $95 \%$ confidence interval) was observed in the $\mathrm{NO}_{2}$ data generated. Within and around the composting facility, $\mathrm{NO}_{2}$ range of $1.15 \mathrm{ppb}\left(2.20 \mu \mathrm{gm}^{-3}\right)-2.14 \mathrm{ppb}$ $\left(4.08 \mathrm{\mu gm}^{-3}\right.$ ) was measured. The highest $\mathrm{NO}_{2}$ load was measured at the monitoring site $\mathrm{B}$ ( $500 \mathrm{~m}$ from the facility) with a range of $2.84 \mathrm{ppb}\left(5.42 \mu \mathrm{gm}^{-3}\right)-6.54 \mathrm{ppb}\left(12.49 \mu \mathrm{gm}^{-3}\right)$. At monitoring site $\mathrm{C}$, very low $\mathrm{NO}_{2}$ load was also observed. Perfect compliance with the national and international regulatory limits for $\mathrm{NO}_{2}$ was observed at all the monitoring sites.
\end{abstract}

Keywords: Composting Facility; Nitrogen dioxide; Bacterial load.

Air Pollution Research Group, Chemistry Department, University of Benin, Benin City, Nigeria,

Researchers of Microbiology Department, University of Benin, Benin City, Nigeria.

Author for correspondence: ukpebehi@uniben.edu 


\section{Resumo}

Numa fábrica de adubo em Eruemu, Nigéria, avaliou-se o impacto do dióxido de nitrogênio e da carga de micróbios no ar do interior e ao redor dela. Avaliações prévias do ar ambiente indicaram que o seu funcionamento poderia ser uma fonte significativa de $\mathrm{NH}_{3} \mathrm{H}_{2} \mathrm{~S}$. Neste estudo, a monitoração do dióxido de nitrogênio foi feita a cada quatro noites, usando-se tubos de difusão Palmes. Para a avaliação de microrganismos, amostras de ar foram coletadas usando-se o método de filtração descrito por Albrecht. A população total de bactérias heterotróficas variou entre $1 \mathrm{cfu} / \mathrm{ml}$ e $67 \mathrm{cfu} / \mathrm{ml}$, sendo sua contagem mais elevada no ponto B. Nenhuma bactéria patogênica foi detectada nas amostras de ar coletadas nos diferentes locais. Baixos níveis de $\mathrm{NO}_{2}$ foram detectados em todos os locais monitorados, apenas uma variação significativa $(\mathrm{p}<0,05)$ foi observada no interior e ao redor da fábrica $1,15 \mathrm{ppb}\left(2,20 \mu \mathrm{gm}^{-3}\right)-2,14 \mathrm{ppb}\left(4,08 \mu \mathrm{gm}^{-3}\right)$, respectivamente. A maior concentração de $\mathrm{NO}_{2}$ foi detectada no ponto de monitoração $\mathrm{B}$ (a $500 \mathrm{~m}$ da fábrica) com uma variação de $2,84 \mathrm{ppb}\left(5,42 \mu \mathrm{gm}^{-3}\right)-6,54 \mathrm{ppb}\left(12,49 \mu \mathrm{gm}^{-3}\right)$. No ponto C observou-se uma baixa concentração de NO Em todos os locais de monitoração foi observada uma perfeita obediência aos limites nacionais e internacionais de $\mathrm{NO}_{2}$.

Palavras-chave: Fábrica de adubos em Eruemu; Dióxido de nitrogênio; Concentração de bactérias.

\section{Introduction}

This study became necessary in order to either douse the anxiety expressed or recommend an urgent precautionary measure based on the fear expressed by the host community on the operation of this facility. The major complain has been on the quality of rainwater collected about $2 \mathrm{~km}$ from the facility. Secondly, the rumor that respiratory ailment has increased in the host community since the inception of this project is also rife. Furthermore, there have been reported isolated cases of hypersensitivity pneumonites, which have been ascribed to high microbial load in air. It is significant to state that the anxiety and fear expressed by this community is not unfounded. Previous study conducted by Ukpebor and Igbafe (1) on the quality of air within and around the facility, revealed that the operation of the facility could be a serious source of $\mathrm{NH}_{3}$ and $\mathrm{H}_{2} \mathrm{~S}$. A similar study on the effect of a medical waste incinerator on the ambient dose of TSP and $\mathrm{NO}_{2^{\prime}}$, showed a negative impact of the incinerator on the ambient level of TSP (2). In the presence of biodegradable wastes, gaseous pollutants and microorganisms are produced in composting sites by anaerobic degradation. The presence of pathogenic microorganism at the composting site could also be attributed to the human activities. Humans are possible carriers of microorganisms. Furthermore, nitrogen dioxide could be formed within and around the facility during combustion processes at high temperature through oxidation of the nitrogen in the combustion air and through the combustion of the fuel - bound nitrogen in the diesel powered mechanical shredder. Nitrogen dioxide produced during the above processes is converted to nitric acid in the atmosphere, mainly by gas phase reactions. This release of nitric acid in the atmosphere and its subsequent incorporation into falling raindrops is responsible for rainfall acidity. However, $\mathrm{NO}_{2}$ athigh concentration causes lung injury (3). Short - term exposure may exacerbate asthma and $\mathrm{NO}_{2}$ can as well cause serious injury to vegetation (4). The transmission of pathogenic microorganisms such as Mycobacterium tuberculosis, Legionella pneumophila and othernewly recognized pathogens with an airborne transmission route are known to cause severe infections (5). These infections include upper respiratory tract infection, asthma, hypersensitivity, pneumonites as well as other respiratory illnesses. The study of airborne microorganisms has expanded from the traditional arena of transmission of diseases via the respiratory route to include human pathogens but also plant pathogens, opportunistic and nonpathogenic organisms and aerosolized microbial by-product (6). Numerous anthropogenic activities especially agricultural particles and wastewater treatment processes serves as the origin of aerosols in the outdoor environment. The release of biotechnology products developed to enhance agricultural productivity, mineral recovery, oil spill cleanup and toxic waste disposal can also be a source of airborne microorganisms. This study is therefore designed to assess the actual impact of the operation of the facility on the ambient dose of nitrogen dioxide and microbial load within and around the facility. The findings will assist the host community in appreciating the veracity or otherwise of their speculation on the negative 
impact of this facility. It is also anticipated that the conclusion drawn from this study would help in better management of this compost plant.

\section{Materials and Methods}

\section{Study Area}

The work reported here was carried out at the composting facility site located at Eruemu, Ughelli - West local government area of Delta State. The facility is located in an expanse of deforested land measuring about 100 hectares. For the purpose of this study, three sampling locations were created:

Location A: Composting facility site

Location B: $500 \mathrm{~m}$ from the composting facility in the direction of the wind flow and host community.

Location C: Control point covering a distance of about $1 \mathrm{~km}$ in the Leeward direction from the composting facility.

\section{$\mathrm{NO}_{2}$ Monitoring}

$\mathrm{NO}_{2}$ measurement was carried out by using Palmes diffusion tubes. The diffusion tubes used in this study consist of small acrylic tubing $8.20 \mathrm{~cm}$ long with a cross - sectional area of $0.82 \mathrm{~cm}^{2}$, having two stainless steel meshes as support for adsorbent for $\mathrm{NO}_{2}$. The sensitivity and utmost accuracy of this particular tube length and the selectivity and specificity of triethanolamine for $\mathrm{NO}_{2}$ have been documented $(7,8)$. In preparing the tubes, uniformity was maximized, for example, the same drying time for each of the steel grids, a freshly prepared triethanolamine/acetone mixture. The required steel grids were cleaned with acetone and dried properly. A mixture of two parts of acetone and one part of triethanolamine was prepared and stirred propenly. The grids were dipped in the mixture and dried for at most 20 minutes. Dipping in solution prior to assembly has been found to give significant more precise $\mathrm{NO}_{2}$ concentrations than from pipetting method (9). After drying, two of the steel grids were placed at one end of the tube and the tube was capped. The prepared tubes were stored in a refrigerator and finally exposed at the different monitoring sites. 14 days sampling duration was observed and monitoring was done for the dry season months of December 2004, January and February 2005. Two tubes from each prepared set were retained in storage as 'blanks' for later analysis with the exposed tubes. After exposing the passive samplers, the collected amount of $\mathrm{NO}_{2}$ was determined colorimetrically as nitrite with Saltzmann reagent (10). A clean visible spectrophotometer (Spectronic 21D) at zero extinction previously calibrated with known concentrations of nitrite $\left(\mathrm{NO}_{2}^{-}\right.$ ) was used to determine the absorbance of both blanks and the air samplers at $540 \mathrm{~nm}$ (using the reagent as referenced). Absorbance readings from unexposed 'blank' diffusion tubes were averaged for each preparation set and the value subtracted from the readings for exposed tubes. The atmospheric concentration of $\mathrm{NO}_{2}$ obtained during the measuring period was calculated as described in Palmes et al.(10), using Fick's First law, and the dimensions of the tube and the diffusion coefficient of $\mathrm{NO}_{2}$ in air.

\section{Estimation of microbial population}

The air was passed through a Millipore filter paper with a pore size of about $0.45 \mu \mathrm{m}$ at a rate of 5L/min for 1 hour and used for bacteriological analyses. The membrane filter was aseptically used to inoculate MF - Endo and MFC - Media and incubated at $34^{\circ} \mathrm{C} / 24 \mathrm{hr}$ and $45^{\circ} \mathrm{C} / 48 \mathrm{hr}$ respectively.

\section{Characterization of the bacterial isolates}

The physiological, bacteriological and biochemical characteristics of the bacterial isolate were determined according to the standard methods described by Gerhardt (11) and standard reference method of Buchannan and Gibbons (12).

\section{Results and Discussion}

\section{$\mathrm{NO}_{2}$ Distribution}

The time weighted average $\mathrm{NO}_{2}$ concentration obtained from the sampling locations 
for the dry season months of December, January and February, are presented in Table 1. Table 2 shows the mean, variance and standard error values. As seen in Tables 1 and 2, low levels of $\mathrm{NO}_{2}$ were obtained at the sampling sites for the period monitored. The $\mathrm{NO}_{2}$ data generated in this study are inferred to be low when compared with the Federal Environmental Protection Agency (13) allowed daily average limit of $75-113 \mu \mathrm{gm}^{-3}$, the US National Ambient $\mathrm{NO}_{2}$ Air Quality Standard of

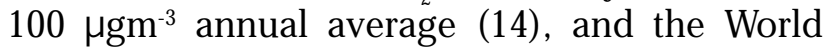
Health Organization annual $\mathrm{NO}_{2}$ guideline of

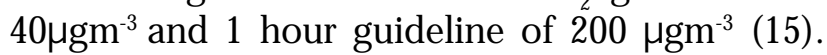
The above comparison indicates perfect compliance with set National and International standards at all the sampling sites surveyed. This observation weakens the tenaciously held view of the host community (about $2 \mathrm{~km}$ from the facility) that the operation of the compost plant was impacting negatively and deleteriously on their health and the quality of the rainwater collected. However, obvious spatial variations were noticed in the $\mathrm{NO}_{2}$ data generated. The highest $\mathrm{NO}_{2}$ level of $6.54 \mathrm{ppb}$ $\left(12.49 \mu \mathrm{gm}^{-3}\right)$ was measured at sampling site B (500 $\mathrm{m}$ from the composting plant). At the monitoring site $\mathrm{A}$ (within the plant), $\mathrm{NO}_{2}$ range of $1.15 \mathrm{ppb}$ $\left(2.20 \mu \mathrm{gm}^{-3}\right)-2.14 \mathrm{ppb}\left(4.08 \mu \mathrm{gm}^{-3}\right)$ was obtained. At the sampling site $\mathrm{C}$ ( $1 \mathrm{~km}$ from the facility), the highest and lowest $\mathrm{NO}_{2}$ loads of $1.13 \mathrm{ppb}$ (2.15 $\left.\mu \mathrm{gm}^{-3}\right)$ and $2.16 \mathrm{ppb}\left(4.12 \mu \mathrm{gm}^{-3}\right)$ were obtained respectively. What this observation suggests is that the operation of the composting plant is not contributing significantly to the $\mathrm{NO}_{2}$ distribution in that environment, since very low concentrations were measured within and around the facility. It is relevant to indicate that the main anthropogenic source of $\mathrm{NO}_{2}$ in the troposphere is actually traffic emissions that account for up to $70 \%$ of ground level concentrations (16). Though stationary sources such as the combustion of the fuel - bound nitrogen in the diesel powered mechanical shredder could be a source of $\mathrm{NO}_{2}$, the empirical evidence from this study reveals insignificant contribution. The most reasonable explanation for the concentrations of $\mathrm{NO}_{2}$ obtained in location $\mathrm{B}$, is the contribution from the flare gases of the flow station of a major oil company located about $350 \mathrm{~m}$ from this sampling spot. At sampling site $\mathrm{C}$, very low levels of $\mathrm{NO}_{2}$ were again recorded. This again reinforces the reasoning that the flare gases and not the composting plant influence sampling location B loads. Furthermore, for all the three months monitored (December, January and February), their $\mathrm{p}$ - values were far less than 0.05 (i.e. at 95\% Confidence Interval), confirming that the differences observed in the concentrations from the three monitoring sites were statistically significant with the highest levels recorded at Site B.

\section{Table 1: Measured $\mathrm{NO}_{2}$ Concentration at the different monitoring sites for the Sampling duration.}

\begin{tabular}{|c|c|c|c|c|c|c|c|}
\hline \multirow{2}{*}{\begin{tabular}{|l} 
Month \\
Decembe
\end{tabular}} & \multirow{4}{*}{$\begin{array}{l}\text { Monitoring Site } \\
\text { A (By the Facility) } \\
\text { B ( } 500 \mathrm{~m} \text { from the facility) } \\
\text { C (1 km from the facility) }\end{array}$} & \multicolumn{6}{|c|}{$\mathrm{NO}_{2}$ Concentration ppb $\left(\mu \mathrm{gm}^{-3}\right)$} \\
\hline & & $1.23(2.35)$ & $1.17(2.24)$ & $1.15(2.20)$ & $2.14(4.05)$ & $1.68(3.21)$ & $1.16(2.22)$ \\
\hline & & $5.45(10.41)$ & $6.54(12.49$ & $4.43(8.46)$ & $6.03(11.52)$ & $4.58(8.75)$ & $3.85(7.35)$ \\
\hline & & $1.90(3.63)$ & $1.63(3.11)$ & $1.42(2.71)$ & $1.24(2.37)$ & $1.28(2.45)$ & 1.79 (3.42) \\
\hline \multirow[t]{3}{*}{ January } & A (By the Facility) & $1.24(2.37)$ & $1.71(3.27)$ & $1.16(2.22)$ & $1.22(2.33)$ & $1.58(3.02)$ & $1.17(2.24)$ \\
\hline & B (500 $\mathrm{m}$ from the facility) & $4.14(7.90)$ & $4.30(8.21)$ & $3.27(6.25)$ & $3.52(6.72)$ & $4.79(9.15)$ & $3.72(7.11)$ \\
\hline & $\mathrm{C}$ (1 km from the facility) & $1.78(3.40)$ & $1.80(3.44)$ & $1.26(2.41)$ & $1.79(3.47)$ & $1.64(3.13)$ & $1.79(3.42)$ \\
\hline \multirow[t]{3}{*}{ February } & A (By the Facility) & $1.90(3.63)$ & $1.63(3.10)$ & $1.42(2.72)$ & $1.24(2.37)$ & $1.28(2.48)$ & $1.79(3.42)$ \\
\hline & B (500 $\mathrm{m}$ from the facility) & $4.02(7.68)$ & $4.28(8.14)$ & $3.29(6.28)$ & $3.39(6.48)$ & $3.22(6.15)$ & $2.84(5.42)$ \\
\hline & $\mathrm{C}$ (1 km from the facility) & $1.56(2.98)$ & $1.68(3.20)$ & $1.37(2.62)$ & $1.90(3.63)$ & $2.16(4.13)$ & 1.39 (3.42) \\
\hline
\end{tabular}

FEPA regulatory limit $\left(75-113 \mu \mathrm{gm}^{-3}\right)$; WHO regulatory limit $40 \mu \mathrm{gm}^{-3}$ 
Table 2: Mean concentration of $\mathrm{NO}_{2}$ measured from the monitoring sites.

\begin{tabular}{|l|l|l|l|l|l|}
\hline Month & $\begin{array}{l}\text { Monitoring } \\
\text { Site }\end{array}$ & $\begin{array}{l}\mathbf{M e a n ~ N O}_{\mathbf{2}} \\
\mathbf{\mu g m}^{-3} \mathbf{)}\end{array}$ & Variance & S.E. & p - value \\
\hline December & A & $2.72 \pm 0.41$ & 0.16 & 0.17 & \\
& B & $9.84 \pm 1.03$ & 1.07 & 0.42 & $5.74451 \mathrm{E}-08$ \\
& C & $2.94 \pm 0.27$ & 0.074 & 0.11 & \\
\hline January & A & $2.57 \pm 0.24$ & 0.06 & 0.97 & \\
& B & $7.56 \pm 0.56$ & 0.31 & 0.23 & $5.24674 \mathrm{E}-09$ \\
& C & $3.20 \pm 0.21$ & 0.04 & 0.09 & \\
\hline \multirow{2}{*}{ February } & A & $2.95 \pm 0.27$ & 0.07 & 0.11 & \\
& B & $6.70 \pm 0.54$ & 0.29 & 0.22 & $3.1109 \mathrm{E}-07$ \\
& C & $3.33 \pm 0.11$ & 0.08 & 0.11 & \\
\hline
\end{tabular}

\section{Bacterial Load}

The total heterotrophic population of the three studied sites varied from site to site with Site B showing the highest bacterial population for the months of December 2004 and January 2005 at Eruemu, Ughelli (Tables 3a and $3 \mathrm{~b})$. The bacterial isolates from the sampled air were identified to be, Escherichia coli, Staphylococcus aureus and Clostridium sp. The low total heterotrophic bacterial population recorded at the sampling sites was agreeable to similar results reported by Erington and Powell on the outdoor air studies (17). The degree of microbial contamination of the outside air depends on a number of factors such as density, humidity, as well as the direction and speed of the wind and the time of day and the season of the year $(6,18,19)$. The direction of wind flow may have accounted for the relatively high bacterial load recorded for site B compared to other studied sites.

Table 3a: Estimated Heterotrophic Population in air samples from composting facility site for the month of December 2004.

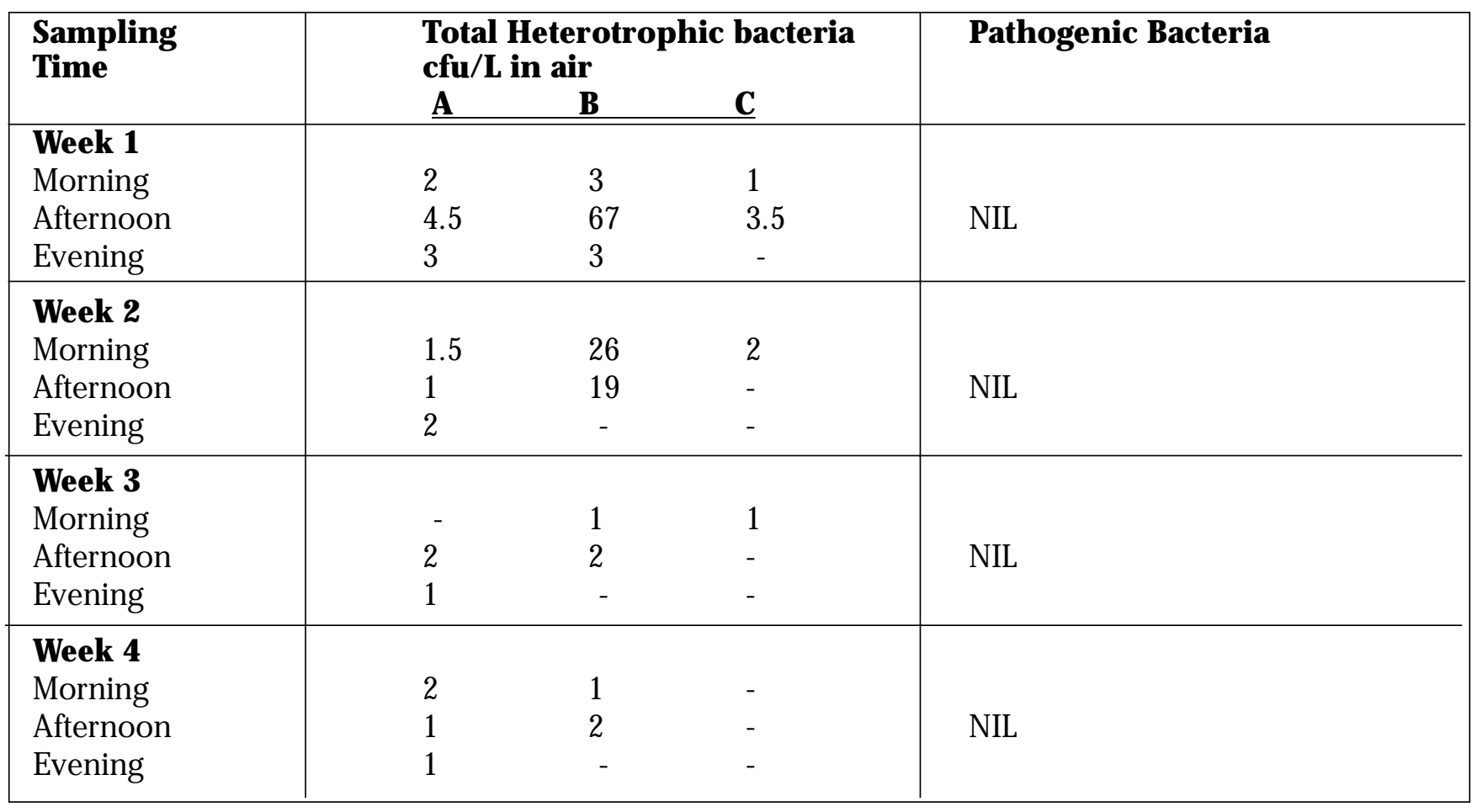




\section{Table 3b: Estimated Bacterial Population in air samples from composting} facility site for the month of January 2005

\begin{tabular}{|c|c|c|c|c|}
\hline $\begin{array}{l}\text { Sampling } \\
\text { Time }\end{array}$ & \multicolumn{3}{|c|}{$\begin{array}{l}\text { Total Heterotrophic bacteria } \\
\text { cfu/L in air }\end{array}$} & Pathogenic Bacteria cfu/L in air \\
\hline \multicolumn{5}{|l|}{ Week 1} \\
\hline Morning & 1 & 6 & 2 & \\
\hline Afternoon & 4 & 7 & - & NIL \\
\hline Evening & - & - & - & \\
\hline \multicolumn{5}{|l|}{ Week 2} \\
\hline Morning & - & 3 & 5 & \\
\hline Afternoon & 7 & 6 & - & NIL \\
\hline Evening & 1 & - & - & \\
\hline \multicolumn{5}{|l|}{ Week 3} \\
\hline Morning & 5 & 1 & 1 & \\
\hline Afternoon & 1 & 5 & - & NIL \\
\hline Evening & - & - & 2 & \\
\hline \multicolumn{5}{|l|}{ Week 4} \\
\hline Morning & 1 & 2 & 1 & \\
\hline Afternoon & 1 & 2 & - & NIL \\
\hline Evening & - & - & - & \\
\hline
\end{tabular}

\section{Conclusion}

This study reveals that the operation of this composting facility has no significant contribution to $\mathrm{NO}_{2}$ load in the environment. Though $\mathrm{NO}_{2}$ is one of the acidic gases that can contribute to rain water acidity, the very low $\mathrm{NO}_{2}$ concentrations obtained in this study indicate that the operation of this facility is not contributing to the acidic nature of the rain water collected in the host community. The low bacterial counts and the absence of nonpathogenic bacterial from the sampled air, therefore pose no environmental hazard to the community.

\section{References}

1 Ukpebor EE, Igbafe, AI. Assessment of the Ambient Air Within and around Eruemu Composting facility. NJEM 2002; 2(4): 35 - 39.
2 Ukpebor EE, Ukpebor, JE, Efebomo, G. Assessment of the effect of a medical waste incinerator on the ambient dose of TSP and NO2. Intern Jour Chem 2004; 14(2): 111 - 117.

3 Marrow, DE. Toxicological data on $\mathrm{NO}_{2}$. An overview. J Toxicological Environ Health 1984; 13: 205 - 227.

4 Samet, JM, Utell, MJ. The risk of $\mathrm{NO}_{2}$ : What have we learned from epidemiological and clinical studies. Toxicol Ind Health 1990; 6: $247-262$.

5 Woodward ED, Friedlander B, Lesher JR, Font W, Kinsey B, Hearne TF. Outbreak of hypersensitivity pneumonitis in an industrial settling. JAMA 1988; 259: 1965 - 1969.

6 Stetzenbach, DL Introduction to Aerobiology. In: Hurst JC, Knudsen R G, Mclnerney JM, Stetzenbach, DL, Walter VM. (Eds.). Manual of Environmental Microbiology. Washington D.C.: ASM Press; 1997. 619- 628. 
7 Gold, A. Stoichiometry of nitrogen dioxide determination in triethanolamine trapping solution. Anal Chem 1977; 49: 1448 - 1450.

8 Ukpebor EE, Ahonkhai SI, Heydtmann $\mathrm{H}$. $\mathrm{NO}_{2}$ measurement with a passive sampler: Assessment of the sensitivity of two types of Palmes Diffusion Tubes for $\mathrm{NO}_{2}$. Intern J Environ Studies 2004; 61(1): 67 - 71.

9 Hamilton RP, Heal MR. Evaluation of methods of preparation of passive diffusion tubes for measurement of ambient nitrogen dioxide. J Environ Monit 2004; 6: 12 - 17.

10 Palmes E D, Gunnison AF, DiMattio J, Tomczyk, C. Personal sampler for nitrogen dioxide. Am Ind Hyg Assoc J 1976; 37: 570 - 577.

11 Gerhardt P, Murray RGE, Wood WA, Krieg NR. Methods for General and Molecular Bacteriology. Washington: ASM; 1994.

12 Buchanan RE, Gibbons NE. Bergey's Manual of Determinative Bacteriology. $8^{\text {th }}$ ed. Baltimore: Williams and Wilkins; 1974.

13 Federal Environmental Protection Agency. Guidelines and Standards for Environmental Pollution control in Nigeria; 1991.
14 USEPA. User's guide for the urban Airshed modes, volume 1: user's manual for UAM (CB4), EPA - 450/4 - 90 - 007a. Office of Air quality planning and standards, US Environmental Protection Agency, Research Triangle Park, NC; 1990.

15 WHO. Guidelines for Air Quality. Geneva, Switzerland; 2000.

16 Simpson D, Perrin DA, Varey JF, Williams, ML. Dispersion modeling of nitrogen oxides in the United Kingdom. Atmos Environ 1990; 24(B): 1713 - 1733.

17 Errington FP, Powell EO. A cyclone separator for aerosol sampling in the field. J Hyg (Lond) 1969; 67(3): 387-399.

18 Mitchell, R. Introduction to Environmental Microbiology. New York: Prentice-Hall International; 1974. 355p.

19 Pelczar JM, Reid, DR. Microbiology. $4^{\text {th }}$ edn. New York: McGraw-Hill Book; 1972.

Recebido em / Received: January 9, 2006. Aceito em / Accepted: February 1st, 2006. 